Pedagogik Jurnal Pendidikan, Maret 2017, Volume 12 Nomor 1 , (43-50)

\title{
Peningkatan Kemampuan Menulis Pengalaman Dengan Menggunakan Bahasa yang Berkesan dengan Menggunakan Model Scaffolded Writing
}

\author{
Oleh : Ningrum Sudianto *
}

\begin{abstract}
Abstrak
Upaya untuk memotivasi belajar peserta didik diarahkan kepada proses belajar mengajar, dalam hal ini penggunaan model pembelajaran yang baik dan benar dalam rangka pencapaian tujuan yang optimal disesuaikan dengan kegiatan belajar mengajar yang berlangsung. Karena adanya penataan dan perencanaan yang baik dan optimal terutama dalam penggunaan model pembelajaran yang tepat dan sesuai dalam proses pembelajaran maka dapat menghasilkan peserta didik yang mempunyai potensi serta memiliki kemampuan intelektual sehingga dapat meningkatkan motivasi belajarnya. Pada pembelajaran Bahasa Indonesia, banyak hal yang menuntut peserta didik untuk dapat menulis dengan benar dengan kosa kata yang baik,tepat dan benar. Di sisi lain guru berusaha menjelaskan dan memberikan kesan yang bermakna kepada peserta didik untuk memahami materi yang dipelajarinya. Belajar akan lebih bermakna jika peserta didik mengalami sendiri apa yang dipelajarinya.
\end{abstract}

\section{Kata Kunci: Menulis, Model, Scaffolded Writing.}

\section{PENDAHULUAN}

Pada saat rangka mengimplementasikan fungsi dan tujuan pendidikan nasional di atas, berbagai komponen pendidikan harus saling mendukung, antara lain: guru, kurikulum, sumber belajar, dan metode pembelajaran. Murid sebagai sasaran pembelajaran, dituntut untuk meningkatkan kemampuan belajarnya sehingga dapat memiliki prestasi belajar yang baik, diantaranya melalui model pembelajaran.

Bagi pengajar bahwa salah satu hal yang sangat penting untuk membuat pembelajaran menjadi efektif adalah pemilihan dan penggunaan model pembelajaran yang sesuai dengan topiktopik mata pelajaran yang diajarkan, khususnya dalam melakukan komunikasi dengan peserta didik agar mereka mudah memahami informasi yang disampaikan sehingga pengetahuan yang didapat akan lebih berkualitas dan sesuai dengan yang diharapkan. Proses komunikasi, utamanya dalam lingkungan pendidikan formal (sekolah) seorang guru dituntut untuk dapat menyampaikan atau menginformasikan pengetahuan yang dimilikinya kepada peserta didik yang diajarkan dalam suatu kegiatan pembelajaran dengan tujuan agar pengetahuan yang dimiliki guru dapat dikuasai oleh peserta didik. Sehingga dengan adanya proses komunikasi tersebut guru diharapkan dapat menyampaikan pengalamannya atau pengetahuannya kepada peserta didik agar peserta didik dapat menerima atau memahami apa yang disampaikan oleh gurunya.

Dengan demikian kegiatan pembelajaran akan lebih bermakna bagi peserta didik. Meskipun demikian upaya tersebut tidak selalu sesuai apa yang kita harapkan, karena dalam kegiatan pembelajaran proses komunikasi tidak selalu berjalan dengan lancar, bahkan dapat menimbulkan kebingungan dan salah pengertian.

Pemberikan materi tanpa memberitahukan pengetahuan yang kongrit atau alat peraga sesuai materi yang di ajarkan. Guru mendiktekan materi pelajaran sementara peserta didik diminta untuk mendengarkan 
dan mencatat apa yang didiktekan oleh gurunya. Peserta didik hanya sekedar sebagai pendengar pasif dalam kelas. Peserta didik kurang berminat belajar, bahkan kehilangan motivasi belajarnya dan mudah jenuh.

Selama ini dalam proses pembelajaran kurang memberikan kesempatan kepada peserta didik untuk melakukan menulis pengalaman yang berkesan ( menulis karngan ) agar dapat menambah wawasan peserta didik untuk dapat meningkatkan kemampuan menulis pengalaman yang berkesan.

Pembelajaran yang dapat melatih peserta didik untuk mencairkan ketegangan didalam kelas dan menemukan sendiri permasalahan yang dihadapi tersebut juga diperluksn. sehingga dapat menghayati dan memahami materi pelajaran yang diberikan.

Untuk meningkatkan hasil belajar peserta didik pada kemampuan menulis pada pelajaran Bahasa Indonesia kelas V, maka salah satu cara yang diharapkan dengan meningkatkan kemampuan dan prestasi belajar peserta didik adalah dengan menggunakan bahasa indonesia supaya peserta didik lebih memahami materi pembelajaran yang dipelajari dan membuat peserta didik tidak mudah bosan dan jenuh sehingga akan lebih menyenangkan dalam proses pembelajaran. Dengan begitu model ini akan membuat peserta didik lebih mudah mengerti dan memahami materi yang disampaikan oleh guru.

Penggunaan bahasa indonesia ini penting karena terkait dengan keberhasilan dan kemampuan peserta didik secara utuh. Bahasa indonesia merupakan jenis model yang sangat menyenangkan yang akan mengakrabkan antarsiswa, mencairkan ketegangan di dalam kelas, melatih ketelitian para siswa serta mengasah kemampuan berfikir dan mengingat tentang pelajaran yang sudah dipelajari, model ini dapat membantu peserta didik dalam belajar Bahasa Indonesia sebab peserta didik mengalami dan berhadapan langsung dengan objek yang sedang dipelajari. Karena peserta didik mengalaminya sendiri, sehingga peserta didik mengetahui sendiri hasil yang didapat dari pengalaman tersebut. Pengalaman tersebut akan membuat wawasan dan pengetahuan siswa bertambah.

\section{STUDI LITERATUR}

Menurut Dwi Kusumaningsih (2013 : 14 )

Bahasa adalah sistem lambang - lambang berupa seperangkat bunyi yang bersifat arbiter dan tidak dapat diramalkan .

Pada pendapat diatas dapat disimpulkan bahwa bahasa indonesia adalah alat berkomunikasi atau berinteraksi antar sesama manusia berupa bunyi yang bersifat arbiter.

Menulis dapat didefinisikan melalui berbagai sudut pandang. dalam sudut pandang yang paling sederhana, menulis dapat diartikan sebagai proses menghasilkan lambang bunyi. Menulis pada dasarnya adalah proses untuk mengemukakan ide dan gagasan dalam bahasa tulis.

Menurut akhadiah ( Yunus Abidin 2012 : 14 ):

Menulis adalah sebuah proses, proses penuangan gagasan atau ide ke dalam bahasa tulis yang dalam praktiknya proses menulis diwujudkan dalam beberapa tahapan yang merupakan satu sistem yang utuh.

Menurut Gie ( Yunus Abidin ( 2012: 14 ) :

Menulis memiliki kesamaan makna dengan mengarang yaitu segenap kegiatan seseorang mengungkapkan gagasan dan menyampaikannya melalui bahasa tulis 
kepada pembaca untuk dBahasa Indonesiahami.

Pada pendapat diatas dapat disimpulkan bahwa menulis adalah sebuah proses berkomunikasi secara tidak langsug antara penulis dengan pembacanya. Sebuah tulisan dibuat untuk dBahasa Indonesiahami maksud dan tujuannya sehingga proses yang dilakukan penulis tidaklah sia- sia.

Mengarang adalah segenap rangkaian kegiatan seseorang mengungkapkan gagasan dan menyampaikannya melalui bahasa tulis kepada masyarakat pembacauntuk dBahasa Indonesiahami ( Gie,2002: 3 ).

Mengarang merupakan segenap rangkaian kegiatan seseorang mengungkapkan buah pikirannya melalui bahasa tulis untuk dibaca dan dimengerti oleh orang lain. Buah pikiran itu dapat berupa pengalaman, pendapat, pngetahuan, keinginan perasaan ampai gejolak kalbu seseorang . buah pikiran ini diungkapkan dan disampaikan kepad pihak lain dengan wahana berupa bahasa tulis, yakni bahasa yang tidak menggunakan peralatan bunyi dan pendengaran melainkan berwujud sebagi tanda dan lambang yang harus dibaca.

Wujud karangan dapat berupa pengalaman, pendapat, pengetahuan, keiginan perasaan smpai gejolak kalbu seseorang. Buah pikiran ini diungkapkan dan disampaikan kepad pihaklain dengan wahana berupa bahas atulis, yakni bahasa yang tidak menggunakan peralatan bunyi dan pendengaran melainkan berwujud sebagai tanda dan lambang yang harus dibaca.

Model pembelajaran adalah suatu perencanaan atau suatu pola yang digunakan sebagai pedoman dalam merencanakan pembelajaran dikelas. Model pembelajaran mengacu pada pendekatan pembelajaran yang akan digunakan termasuk didalamnya tujuan -tujuan pengajaran,dan pengelolaan kelas ( Arends dalam Trianto, 2010 : 51 ). Sedangkan menurut Jovce dan Weil (1971) dalam Mulyani Sumantri, dkk (1999 : 42) model pembelajaran adalah kerangka konseptual yang melukiskan prosedur yang sistematis yang mengorganisasikan pengalaman belajar untuk mencapai tujuan pembelajaran tertentu, dan memiliki fungsi sebagai pedoman bagi paraperancang pembelajaran dan para pengajar dalam merencanakan dan melaksanakan aktifitas belajar mengajar.

Berdasarkan dua pendapat diatas di atas, maka dapat disimpulkan bahwa model pembelajaran adalah kerangka konseptual yang melukiskan prosedur sistematik dalam mengorganisasikan pengalaman belajar untuk mencapai tujuan pembelajaran tertentu dan berfungsi sebagai pedoman bagi perancang pembelajaran dan para guru dalam merancang dan melaksanakan proses belajar mengajar.

Menurut Tritanto ( 2010 : 53 ) fungsi model pembelajaran adalah sebagai pedoman bagi perancang pengajar dan para guru dalam melaksnakan pembelajaran. Untuk memilih model ini sangan dipengaruhi oleh sifat dari materi yang akan diajarkan, dan juga dipengaruhi oleh tujuan yang akan dicapai dalam pengajaran tersebut serta tingkat kemmpuan peserta didik. Di samping itu pula, setiap model pembelajaran juga mempunyai tahap tahap (sintaks ) yang dapat dilakukan siswa dengan bimbingan guru. Antara sintaks yang satu dengansintaks yang lain juga mempunyai perbedaan. Perbedaan perbedaan ini diantaranya pembukaan dan penutupan pembelajaran yang berbeda antara satu dengan yang lain. Oleh karena itu, guru perlu menguasai dan dapat menerapkan berbagai keterampilan mengajar, agar dapt mencapai tujuan 
pembelajaran yang beraneka ragam dan lingkungan belajar yang menjadi ciri sekolah pada dewasa ini. Menurut Kardi dan Nur dalam Tritanto (2010 : 142) istilah modelpembelajaran mempunyai makna yang lebih luas darBahasa Indonesiada strategi, metode atau prosedur.

Pada akhirnya setiap model pembelajaran memerlukan sistem pengelolaan dan lingkungan belajar yang berbeda. Setiap pendekatan memberikan pesran yang berbeda kepada siswa, pada ruang fisik, dan pada sistem sosial kelas. Sifat materi dari sistem saraf banyak konep dan informasi informasi dariteks buku bacaan, materi ajar siswa, di samping itu banyak kegiatan pengamatan gambar - gambar. Tujuan yang akan dicapai meliputi aspek kognitif ( produk dan proses ) dari kegiatan pemahaman bacaan dan lembar kegiatan siswa (Trianto $2010: 55$ ).

Model scaffoded writing merupakan model pembelajaran menulis yang seluruh perencanaan karangannya ditentukan oleh guru ( Axford et. Al., 2009 : 88 ). Dalam pelaksanaanya guru menjelaskan cara pengarang menulis sebuah tulisan yang digunakan sebagi model. Berdasarkan pengertian ini, model ini berbeda dengan model menulis lainnya yang seluruh perencanaan menulis diserahkan kepada sisw. Dalam model ini perencanaan menulis dijelaskan guru sehingga tulisan yang dihasilkan dari kegitan pembelajaran ini lebih bersifat tulisan rekonstruksi. Siswa hanya akan meniru apa yang dilakukan penulis teks yang dijadikan model. Tujuan utama model ini adalah agar siswa mengetahui bagaimana sebuah karangan dibuat berdasarkan pengimajinasian, pemikiran, dan pengemasan yang dilakukan pengarang.

\section{METODOLOGI}

Penelitian ini dilakasanakan di SDN 3Panarung Palangkaraya yang pada kelas V tahun pelajaran 2016 / 2017 yang belokasi di Jl. jati I. Alasan peneliti melakukan penelitian disekolah ini karena peneliti menemuka fenomena yang menarik yang ada disekolah itu dan sesuai dengan masalah penelitian yang ditemukan peneliti dan dasar-dasar masalah yang terkait dengan variabel.

Jenis penelitian yang digunakan yaitu penelitian tindakan kelas ( PTK ).

Menurut Suharsimi Arikunto (2006: 3) "Penelitian Tindakan Kelas (PTK) merupakan suatu pencermatan terhadap kegiatan belajar berupa sebuah tindakan, yang sengaja dimunculkan dan terjadi dalam sebuah kelas secara bersama.

Menurut McNiff (Supardi, 2006: 102) menyatakan bahwa:

Penelitian Tindakan Kelas (PTK) sebagai bentuk penelitian refrektif yang dilakukan oleh pendidik sendiri terhadap kurikulum, pengembangan sekolah, meningkatkan prestasi belajar, pengembangan keahlian mengajar, dan sebagainya.

Berdasarkan pendapat di atas dapat disimpulkan bahwa penelitian tindakan kelas (PTK) adalah sebagai bentuk penelitian reflektif dan meningkatkan prestasi belajar dalam kegiatan belajar.

Kehadiran dan peran peneliti dalam pelaksanaan penelitian ini adalah sebagai pengajar atau guru model yang melakukan penelitian secara langsung dikelas di dalam kelas V SDN 3-Panarung Palangkaraya. penelitian ini bertujuan untuk pendidik agar lebih terampil dalam memberikan pelajaran dan agar peserta didik supaya lebih aktif. Peneliti bertugas membuat rencana pelaksanaan pembelajaran (RPP) sekaligus menyampaikan bahan ajar selama proses pembelajaran berlangsung

Kehadiran peneliti disini kerja sama 
dengan wali kelas atau teman sejawat untuk berperan sebagai pengamat (observer) yang bertugas mengumpulkan data pada saat proses pembelajaran berlangsung, serta peneliti adalah pihak yang merasakan adanya masalah yang perlu diselesaikan ,peneliti juga sebagai pengampu kelas atau pelajaran yang menjadi kancah penelitian,maka peneliti orang yang pertama yang dapat merasakan adanya masalah.

Adapun Subjek penelitian dalam penelitian ini pada penelitian tindakan kelas adalah seluruh peserta didik kelas $\mathrm{V}$ SDN 3- panarung Palangkaraya berjumlah 27.

Penelitian ini mengunakan rancangan PTK yang didirikan dengan adanya siklussiklus, setiap siklus terdiri empat tahapan yaitu: perencanaan, pelaksanaan tindakan, observasi, dan refleksi evaluasi.Menurut Kemmis dan Taggart "setiap siklus melalui empat tahap yaitu 1) Perencanaan, 2) Pelaksanan, 3) Pengamatan dan observasi, 4) Refleksi".

Refleksi dilakukan setelah tindakan selesai berdasarkan hasil observasi kegiatan guru mengajar dan kemandirian belajar peserta didik. Hasil siklus 1 dinyatakan berhasil apabila pots tes pada penelitian (tes yang dilakukan sesudah tindakan atau siklus 1) meningkat dan nilainya mencapai KKM yaitu 65 dari pre tes (tes yang dilakukan sebelum tindakan atau sebelum dilakukan siklus 1) dan ketuntasan mencapai $85 \%$ atau lebih ,maka tindakan berhenti sampai disiklus 1 . Selanjutnya,apabila siklus 1 tidak berhasil atau post tes yang dilakukan tidak meningkat dari pre tes dan nilainya tidak mencapai KKM 65, maka penelitian dilanjutkan kesiklus berikutnya.

Untuk pengambilan data pada penelitian ini dikumpulkan menggunakan observasi dan tes,observasi digunakan untuk mengumpulakan data tentang kegiatan peserta didik dalam proses belajar mengajar, tes digunakan untuk mendapatkan fakta,pendapat,dan kemampuan peserta didik selama kegiatan menulis pengalaman yang berkesan dalam pelajaran Bahasa Indonesia. Hasilnya dapat digunakan sebagai acuan, selain itu tes juga digunakan sebagai mengukur kemampuan dasar dan pencapaian prestasi. Selain itu tes digunakan sebagai acuan untuk melihat peningkatan kemampuan menulis pengalaman peserta didik dalam mengikuti proses pembelajaran.

Dalam penelitian ini data atau catatan hasil pengamatan yang dikumpulkan berdasarkan lembar observasi bertujuan untuk mengetahui kinerja guru dalam pembelajaran dan aktivitas belajar peserta didik selama proses pembelajaran.

Menurut pendapat Sutrisno Hadi dalam buku Sugiono (2008: 203 "mengemukan bahwa observasi merupakan suatu proses yang kompleks,suatu proses yanvg tersusun dari berbagai proses biologis dan psikologis. Dua yang terpenting adalah proses -proses pengamatan dan ingtan"

Adapun menurut Nasution dalam Sugiono (2008: 310)" :

Observasi adalah dasar semua ilmu pengetahuan,para ilmuan yaitu fakta dapat bekerja berdasarkan data, yaitu fakta mengenai dunia kenyataan yang diperoleh melalui observasi"

Berdasarkan hal tersebut maka dalam penelitian ini dilakukan dengan cara pengamatan langsung kemudian mencatat sesuai kenyaaan yang telah ada. Maka berdasarkan pendapat para ahli diatas dapat disimpulkan bahwa observasi adalah merupakan salah satu cara pengumpulan data yang dilakukan secara langsung dengan mencatat kenyataan yang ada sesuai dengan fakta yang ada dilapangan bisa berbentuk 
catatan,dan data. Observasi yang dilakukan dalam penelitian ini untuk mengamati secara langsung kegiatan dan penelitian peserta didik selama proses belajar mengajar didalam kelas.

Instrument yang harus mempunyai validitas isi adalah instrument yang berbentuk tes untuk mengukur hasil belajar dalam aspek kecakapan akademik. Sebuah tes dikatakan mempunyai validitas isi apabila dapat mengukur tujuan khusus tertentu yang sejajar dengan materi atau isi pelajaran.

Untuk memperoleh soal tes dengan hasil yang baik, maka dilakukan uji coba validitas tes, tes umumnya bersifat mengukur ,tes hasil belajar kadang-kadang disebut juga tes prestasi belajar, mengukur hasil-hasil belajar peserta didik, adapun pengertian validitas isi tes hasil belajar adalah validitas yang diperoleh setelah dilakukan penganalisisan,penelusuran, atau pengujian tes terhadap isi yang terkandung dalam tes hasil belajar.tes hasil belajar juga dibedakan menurut materi yang diukur,sesuai dengan nama-nama mata pelajaran atau bidang study yang dipelajari.

Validitas isi dapat dibantu dengan menggunakan kisi-kisi instrument,atau matrik pengembangan instrument, dalam kisi-kisi terdapat variabel, yang diteliti, indikator sebagai tolak ukur dan nomor butir (item), pertanyaan atau pertanyaan yang telah dijabarkan dari indikator. Dengan kisi-kisi instrument itu maka pengujian validitas dapat dilakukan dengan mudah dan sistematis.

Instrument dalam penelitian ini meliputi instrument tes dan non tes,instrument tes dalam penelitian ini dilakukan dengan teknik tes tertulis,diberikan kepada peserta didik, pada awal penelitian dan pada akhir tindakan sebagai bukti untuk menunjukan ada atau tidaknya peningkatan keterampilan peserta didik dalam pembelajaran bahasa Indonesia kemampuan menulis laporan pada pelajaran bahasa indonesia,sedangkan instrument non tes yaitu digunakan untuk melihat aktivitas pendidik dan keaktifan peserta didik dalam pembelajaran Bahasa Indonesia

\section{HASIL DAN PEMBAHASAN}

Pembelajaran dapat dikatakan tuntas apabila persentase dalam evaluasi pembelajaran mencapai $85 \%$ dan memperoleh nilai rata-rata 65. Atas dasar data awal inilah, peneliti merasa perlu melakukan tindakan kelas dalam dua siklus untuk pembelajaran Bahasa Indonesia menggunakan model scaffolded writing untuk meningkatkan hasil belajar Bahasa Indonesia pada peserta didik.

Berdasarkan hasil perhitungan rata - rata, maka dapat dilihat hasil nilai rata - rata peserta didik pada tes siklus 1 adalah 58,33.

Menghitung ketuntasan belajar peserta didik secara klasikal, dimana indikator ketuntasan belajar yang ditentukan KKM 65 ketuntasan klasikal

$$
\begin{aligned}
\mathrm{TB} & =\frac{\Sigma_{s} \geq^{65}}{n} \times 100 \% \\
& =14 / 7 \times 100 \% \\
& =0,44 \times 100 \% \\
& =51,85 \%
\end{aligned}
$$

Berdasarkan hasil perhitungan ketuntasan hasil belajar, maka dapat dilihat ketuntasan hasil belajar peserta didik pada tes awal siklus 1 adalah 51,85\%.

Menghitung nilai rata - rata, untuk mengetahui pencapaian nilai ketuntasan minimal peserta didik dengan membagi jumlah nilai seluruh peserta didik dengan jumlah seluruh peserta didik dengan rumus :

Berdasarkan hasil perhitungan rata - rata, maka dapat dilihat hasil nilai rata - rata peserta didik pada tes siklus 2 adalah 82,15. 
Menghitung ketuntasan belajar peserta didik secara klasikal, dimana indikator ketuntasan belajar yang ditentukan KKM 65 ketuntasan klasikal adalah $85 \%$.

$$
\begin{aligned}
\mathrm{TB} & =\frac{\sum s \geq^{65}}{n} \times 100 \% \\
& =\frac{27}{27} \times 100 \% \\
& =1 \times 100 \% \\
& =100 \%
\end{aligned}
$$

Berdasarkan hasil perhitungan ketuntasan hasil belajar, maka dapat dilihat ketuntasan hasil belajar peserta didik pada tes awal siklus 2 adalah $100 \%$.

Melalui pembelajaran menggunakan model scaffolded writing oleh peneliti aktivitas guru dan peserta didik menunjukan suatu peningkatan yang baik. Aktivitas guru pada siklus I memperoleh nilai rata -rata 3,39. Sedangkan pada siklus II ada peningkatan menjadi lebih baik, dengan penilaian rata - rata oleh pengamat sebesar 3,67. Dan aktivitas peserta didik pada siklus I nilai rata-rata 3,08 pada siklus II meningkat menjadi 3,75.

Pada pre tes belum memuaskan karena hanya $2 \%$ peserta didik yang mengalami ketuntasan belajar, pada siklus I persentase ketuntasan belajar peserta didik menagalami peningkatan namun belum mencapai indikator ketuntasan $85 \%$ yang hanya hanya mendapat 51,85 \% dan mendapat nilai rata - rata 60,34 . Pada siklus II nilai peserta didik mengalami peningkatan sangat bagus dengan perolehan nilai rata - rata 82,15 dengan kriteria ketuntasan secara klasikal mencapai $100 \%$. Peneliti menganggap pada siklus II ini sudah berhasil karena telah mencapai nilai KKM dan telah berhasil mencapai nilai ketuntasan secara klasikal.

\section{SIMPULAN}

1. Pada siklus I persentase ketuntasan belajar peserta didik menagalami peningkatan namun belum mencapai indikator ketuntasan $85 \%$ yang hanya hanya mendapat $51,85 \%$ dan mendapat nilai rata - rata 60,34 .

2. Pada siklus II nilai peserta didik mengalami peningkatan sangat bagus dengan perolehan nilai rata - rata 82,15 dengan kriteria ketuntasan secara klasikal mencapai $100 \%$. Peneliti menganggap pada siklus II ini sudah berhasil karena telah mencapai nilai KKM dan telah berhasil mencapai nilai ketuntasan secara klasikal.

\section{REFERENSI}

Abdul Majid, 2013, Strategi Pembelajaran. Bandung : PT REMAJA ROSDAKARYA

Abidin, Yunus. 2014.Pembelaajaran Bahasa Berbasis Pendidikan Karakter.Bandung : Refika aditama.

Ady, S., dkk, 2009, Evaluasi pembelajaran di SD Jakarta: Universitas Terbuka

Sugiyono, (2007). Metode Penelitian Pendidikan. Bandung: Alfabeta.

Sukadji Soetarlinah, (2000). Menyusun dan Mengevaluasi Laporan Penelitian. Jakarta: Penerbit Rajawali.

Sulaeiman, A. H, (2001). Media Audio-Visual untuk Pengajaran, Penerangan, dan Penyuluhan. Jakarta: PT. Gramedia.

Suryabrata Sumadi, (2006). Psikologi Pendidikan. Bandung: Alfabeta.

Suyono \& Hariyanto, (2004). Belajar dan Pembelajaran. Jakarta: Rajawali.

Syah Muhibbin, (2008). Psikologi Belajar. Jakarta: PT Raja Grafindo Persada 
Pedagogik Jurnal Pendidikan, Maret 2017, Volume 12 Nomor 1, (43-50)

Syaodih Sukmadinata Nana, (2004), Landasan Psikologi Proses Pendidikan. Bandung: PT Remaja Rosdakarya.

Tulus Tu'u, (2004). Peranan Disiplin pada Prilaku dan Prestasi Siswa. Jakarta: Grasindo. Wahyu Riyandono ,2013, Penerapan Strategi Think Tlak Write ( TTW )untuk meningkatkan keterampilan menulis laporan siswa kelas VB SDN Wonosari 02 Semarang. 